\title{
Det russiske imperiet: Fra sammenbrudd til triumf
}

\author{
Halvor Tjønn \\ Oslo: Dreyers forlag 2020 \\ 744 sider. ISBN 9788282655378
}

Recenserad av Klas-Göran Karlsson [professor i historia vid Lunds universitet, klas-goran.karlsson@hist.lu.se]

Denna omfångsrika bok är andra delen av en planerad trilogi om Rysslands historia, författad av Halvor Tjønn, som på 1990-talet verkade som korrespondent i Moskva. Första delen, Russland kom til, som omspänner perioden från de östslaviska stammarnas första möte med de skandinaviska vikingarna på 800-talet till Ivan den förskräckliges 1500-tal, utkom 2015. Det russiske imperiet fortsätter redovisningen av den ryska historien från Ivans död via den stora oredans och de första Romanovtsarernas tid till de "stora» ryska härskarna Peter I och Katarina II.

Författaren varnar tidigt i boken läsarna att vi måste vara utrustade med tålamod, och så är det verkligen: det är en nästan alltigenom narrativ historia som förmedlas, fylld med detaljerad information om bemärkta individer, frimodigt recenserade som inkompetenta, svekfulla, dumma, sluga eller maktberusade. Lägg till detta ett myller av årtalsangivelser, äktenskapsförbindelser, inrikespolitiska maktkamper mellan tronpretendenter och militära slag mot grannstater. Kyrkan är den enda institution som kan konkurrera med tsarmakten om uppmärksamheten.

Medan de historiska berättelserna följer på varandra i en oändlig ström, begränsas det större historiska sammanhanget till korta reflektioner i kapitelinledningarna, vilket är synd med tanke på att författaren besitter stor kunskap om den ryska historien. Visserligen skulle man kunna säga att många unika berättelser åtminstone indirekt säger något mer generellt om den ryska maktutövningen och tsarsystemet. När tsaritsan Elisabeth Petrovna, Peter den stores dotter, för att försäkra sig om att bli balernas drottning förbjöd alla sina hovdamer att anlägga samma frisyr som hon själv och, efter en misslyckad hårklippning tvingade sin omgivning att göra sammalunda, samt för säkerhets skull också lät distribuera förfärliga peruker till dem att bära, är det förstås något som illustrerar furstemaktens absoluta, närmast perversa karaktär. Problemet med en sådan framställning blir emellertid att allt i historien blir lika viktigt, vilket blir sak samma som att ingenting blir viktigt. Huvudsak och bisak, fundamentalt och efemärt blir svårt att identifiera. Att tsaritsan under det som brukar 
kallas palatsrevolutionernas epok kom till makten genom en statskupp på bekostnad av den övriga härskarfamiljen, och framför allt den tidigare kejsarinnan Anna Leopoldovna och hennes son Ivan som tvingades tillbringa resten av sina liv i fångenskap, får samma dignitet som frisyrhistorien. Visserligen vittnar Tjønn om risken med att "färgrika personligheter» som Elisabeth Petrovna stjäl uppmärksamheten från den större ekonomiska och politiska utvecklingen, och han tar hjälp av några nutida ryska historiker för att bredda sitt perspektiv till den absoluta furstemaktens Europa och dess allianssystem. Ändå lever han inte riktigt som han lär. Några rader om hennes utrikespolitik får förvisso plats, men det är när han får berätta om hennes relation till den italienske arkitekten Francesco Rastrelli, den mångkunnige vetenskapsmannen Michail Lomonosov och andra män, däribland väldigt många tyskar, som rörde sig $\mathrm{i}$ kretsen runt henne eller om hennes speciella personlighetsdrag, som han trivs bäst. Det är så boken är upplagd, oavsett vilken av Rysslands härskare som gestaltas.

Michail Pokrovskij, den förstalinistiska epokens främste sovjethistoriker, konstaterade en gång att om man kommer för nära historien ser man bara ansikten, och missar därmed de strukturer och relationer som bär upp historien och mer varaktigt bestämmer dess gång. Man behöver inte bekänna sig till sovjethistorikerns historiematerialistiska åskådning för att vara kritisk mot närgångenheten i bokens historieskrivning. Det ryska samhället, dess sociala förhållanden, högadelns kamp mot lågadeln, lyser trots Stenka Razins deltagande i stort med sin frånvaro. Man kan visserligen hävda att vissa upphöjda ryska ansikten har betytt mer för historien än ansikten i andra länder, givet autokratins starka position, men också denna har haft sina samhälleliga och kulturella förutsättningar.

Boken är uppenbart skriven för andra än redan Rysslandskunniga historiker som denne recensent. Recensioner av den första volymen bekräftar att det är den grundliga och faktaorienterade framställningen som värderas positivt, och att även denna bok har dessa kvaliteter kan inte förnekas, inte heller att underhållningsvärdet är högt. Om man däremot är intresserad av historia som vetenskap finns inte så mycket att hämta. Någon ny kunskap förmedlas inte, och något spår av tanken att historia är svar på problem och frågor formulerade från vår tids horisont, intressen eller utvecklingar finns inte heller. Någon redovisning av källmaterialet förekommer knappast, notapparaten till trots, och kritiska granskningar av berättelsernas överensstämmelse med forskningens resultat är inte aktuella. Den stannar inte upp vid analytiska knutpunkter, vid sådant som ter sig oväntat, motsägelsefullt eller på annat sätt intressant, utan bromsar bara in vid varje tillfälle som ges att berätta en historia. Men kanske är detta en alldeles orättvis kritik av en bok som är skriven för andra syften än de vetenskapliga.

Efter nära 700 sidor av narration sammanfattas boken på några få avslutande sidor. Först där formuleras ett antal intressanta analytiska iakttagelser, som i mina ögon borde ha inlett och väglett framställningen. Ett sådant är att tsarens kontinuerliga krig och massakrer på den egna befolkningen gjorde det ryska samhället dåligt rustat för att möta yttre och inre hot. Resultatet blev samhällsupplösning och en rad 


\section{0 | KLAS-GÖRAN KARLSSON}

revolutionära uppror. Den andra sidan av det ryska myntet är tider av utvidgning av territoriet, tider som också innebar konsolidering av självhärskardömets makt, inte minst eftersom det gav tsaren närstående grupper ökat inflytande.

Med Peter den store påbörjades en modernisering av Ryssland, men den begränsades till ekonomisk och militär förändring. Den politiska modernisering som skulle kunna ha inneburit maktdelning och faktiskt ledde till uppror slogs brutalt ned av tsarmakten. Moderniseringen kom att halta. Och till sist noterar Tjønn: »Problemet med overføring av makt fra en hersker til en annen var likevel langt fra løst. I fraværet av en ordnet mekanisme for å erstatte en tsar/tsaritsa med en annen, ble den personen som var i stand til å gripe øyeblikket og mobilisere garderegimentene for sin sak, utropt til hersker over det russiske imperiet” (s. 684). Det är förhoppningen om att sådana återkommande inslag i den rysk-sovjetisk-ryska historien kan få en mer styrande position som gör det värt att vänta på den tredje delen. 